\title{
Trombeaspirasjon ved hjerteinfarkt?
}

\section{Trombeaspirasjon gir ingen til- leggsgevinst ved perkutan koronar intervensjon ved hjerteinfarkt med ST-elevasjon.}

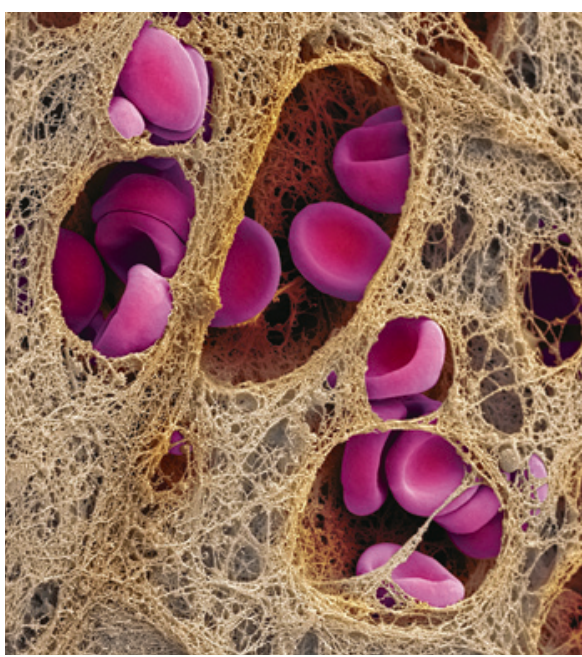

Trombe i koronararterie. Illustrasjonsfoto: Science Photo Library
Perkutan koronar intervensjon, såkalt PCIbehandling, står sentralt $\mathrm{i}$ behandlingen av hjerteinfarkt med ST-elevasjonsinfarkt. Distal trombosering kan være et problem under inngrepet, men det er usikkert om samtidig trombeaspirasjon har noen effekt.

I en studie som nylig er publisert i The Lancet, ble nesten 11000 pasienter med STelevasjonsinfarkt randomisert til PCI-behandling med eller uten trombeaspirasjon (1). Etter ett års oppfølging var det ingen forskjell mellom gruppene hva gjaldt forekomsten av kardiovaskulær død, hjerteinfarkt, kardiogent sjokk eller hjertesvikt, mens det var flere tilfeller av hjerneslag hos dem som hadde fått utført trombeaspirasjon.

- En metaanalyse som er inkludert i samme publikasjon, viser en svak mortalitetsgevinst av trombeaspirasjon, men gevinsten er ikke signifikant, sier overlege Bjørn Bendz ved hjerteavdelingen ved Oslo universitetssykehus. Rutinemessig trombeaspirasjon ved STelevasjonsinfarkt kan derfor ikke anbefales, men det finnes noen pasienter som kan ha nytte av det. Dette må vurderes på individuell basis.
- Denne studien viser viktigheten av at det må utføres flere randomiserte studier med harde endepunkter før man kan konkludere med større sikkerhet. Trombeaspirasjon ved ST-elevasjonsinfarkt gjøres ikke rutinemessig ved norske sykehus som tilbyr PCIbehandling, sier Bendz.

\section{Ketil Slagstad}

Tidsskrifte

\section{Litteratur}

1. Jolly SS, Cairns JA, Yusuf S et al. Outcomes after thrombus aspiration for ST elevation myocardial infarction: 1-year follow-up of the prospective randomised TOTAL trial. Lancet 2015; e-publisert 12.10.2015.

\section{Kan ebola smitte seksuelt?}

\section{Ebola-RNA kan påvises i sæd i flere måneder etter gjennomgått ebola- sykdom.}

Ebola er en av våre mest fryktede virusinfeksjoner, med høy dødelighet. Smittemåten er primært via blod eller kroppsvæsker fra en smittet person - død eller levende. Det har vært uklart i hvilken grad overlevende menn fortsatt utgjør en smitterisiko ved seksuell kontakt. En kvinne i Liberia ble i mars i år smittet etter seksuell kontakt med en overlevende mann (1).

I en ny studie som nylig er publisert i New England Journal of Medicine, ble sædprøver fra 100 menn som hadde overlevd ebolasykdom analysert for ebola-RNA med revers transkriptase-PCR (2). Forekomsten av ebola-RNA var fallende i tiden etter friskmelding, men kunne fortsatt påvises hos om lag en firedel etter 7-9 måneder.

- Denne studien viser at de som overlever ebolasykdom, kan være smittekilder i flere måneder og at nye ebolautbrudd kan skyldes seksuell smitte fra smittebærere lenge etter at de er blitt friske, sier Johan Bruun, professor emeritus i infeksjonsmedisin. - Erfaringene fra epidemien i Vest-Afrika viser dog at smittefaren er meget liten. Smitte kan dess- uten forbygges ved bruk av kondom. Det er viktig at de som overlever ebolasykdom ikke blir stigmatisert, sier Bruun og henviser til en lederartikkel i New England Journal of Medicine (3).

\section{Ketil Slagstad}

Tidsskriftet

\section{Litteratur}

1. Christie A, Davies-Wayne GJ, Cordier-Lasalle T et al. Possible sexual transmission of Ebola virus Liberia, 2015. MMWR Morb Mortal Wkly Rep 2015; 64: 479-81.

2. Deen GF, Knust B, Broutet $\mathrm{N}$ et al. Ebola RNA persistence in semen of Ebola virus disease survivors - preliminary report. N Engl J Med 2015; e-publisert 14.10.2015

3. Sprecher A. Handle survivors with care. N Engl J Med 2015; e-publisert 14.10.2015.

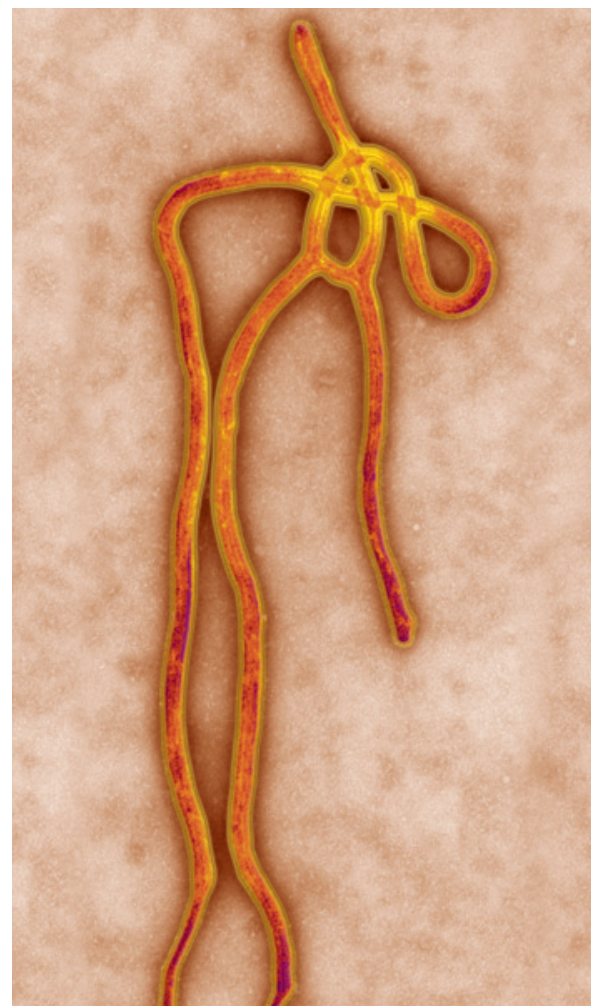

Illustrasjonsfoto: Science Photo Library 